\title{
Calcific tendonitis of longus colli: a rare cause of neck pain
}

Department of ENT, NHS Greater Glasgow \& Clyde, Glasgow, UK

\section{Correspondence to}

Dr Amy Bryce;

amyabryce@gmail.com

Accepted 21 November 2021

Check for updates

(C) BMJ Publishing Group Limited 2022. No commercial re-use. See rights and permissions. Published by BMJ.

To cite: Bryce A, Woodley N, Williamson $\mathrm{A}$, et al. BMJ

Case Rep 2022;15:e247362. doi:10.1136/bcr-2021-

247362

\author{
Amy Bryce, Niall Woodley, Andrew Williamson, Catriona Douglas
}

\section{DESCRIPTION}

A 54-year-old man presented with a 5-day history of progressive left-sided neck pain, stiffness and odynophagia. There was no associated fever, history of trauma or airway compromise. The patient was fit and well with no medical history. Physical examination of the neck revealed severely reduced range of movement in all cervical planes. Oral cavity and neurological examinations were normal, and generalised pharyngeal oedema was seen on flexible nasendoscopy. The patient was apyrexial throughout with other physiological observations within normal limits. Only a mildly raised $\mathrm{C}$ reactive protein was noted on blood work.

The patient was taken for urgent contrast CT neck, revealing a prevertebral fluid collection of unclear aetiology extending from the clivus to the inferior border of C5 (figure 1). An area of calcification was noted below the anterior arch of $\mathrm{C} 1$, in keeping with calcification at the superior insertion of the longissimus coli tendon(figure 2). To further evaluate these findings, MRI neck with contrast was performed 3 days later. This demonstrated a prevertebral fluid collection with enhancement extending down to level of the upper border of T2 and again revealing calcification in the left longus colli muscle.

Along with the differential diagnosis of calcific tendonitis of longus colli (CTLC), the fluid collecting inferior to $\mathrm{C} 1$ could have represented a retropharyngeal abscess-a potentially life-threatening infection. The imaging was reviewed with multiple specialities including radiology, otolaryngology, infectious diseases, neurosurgical and rheumatology teams; concluding that the most likely diagnosis was CTLC with associated oedema creating a fluid collection-supported by the clinical condition of the patient who remained well. Treatment was with regular non-steroidal anti-inflammatory medication with proton pump cover and physiotherapy. Other published cases have described the use of steroids, $\mathrm{H} 2$ antagonists, surgical intervention and cervical collars $^{1}$; however, there is little evidence to support their use.

Current literature describes most CTLC cases to be self-limiting and resolve spontaneously in 1-2 weeks, ${ }^{2}$ as was the case here. Exact aetiology is unknown, however calcification may occur following injury or repetitive trauma, similar to that of calcific tendinitis in other locations. ${ }^{3}$ It later came to light that the patient had been performing extensive pruning of trees prior to presentation requiring prolonged periods of neck extension, while carrying heavy machinery,

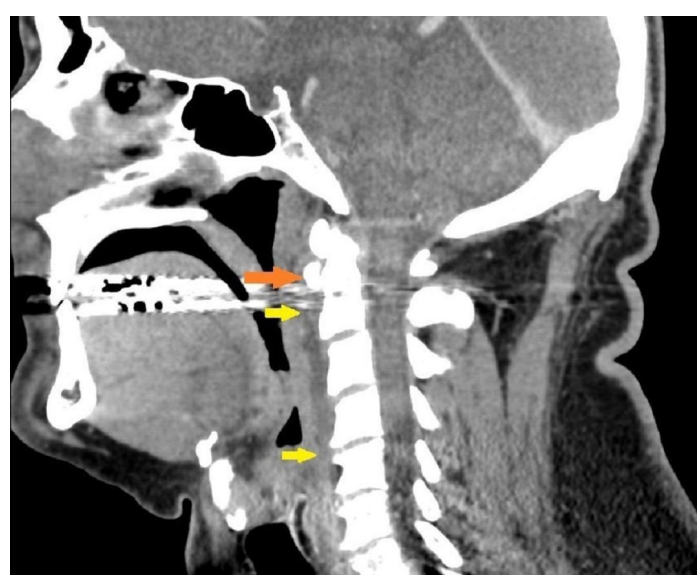

Figure 1 Sagittal CT image showing superior and inferior extent of fluid collection in retropharyngeal space (yellow arrows) and calcification at insertion of longissimus coli (orange arrow).

and episodes of sharp flexion to avoid falling branches.

Although CTLC represents a benign and perhaps under-recognised condition, this case highlights the importance of considering other differential diagnoses in a patient presenting with limited neck movements. This patient was systemically well making a retropharyngeal abscess unlikely, however dismissing this could have had catastrophic consequences for the patient as an abscess would have required prompt airway management and surgical drainage. Literature has demonstrated the pathognomonic finding of prevertebral oedema associated with $\mathrm{CTLC}^{4}$; however, the fluid collection seen here was not immediately characteristic and mimicked a more clinically concerning diagnosis of an abscess. Luckily for this patient, prompt recognition of

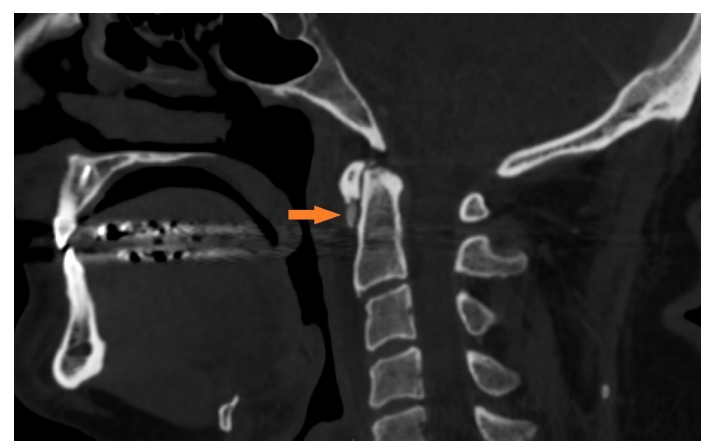

Figure 2 Sagittal CT image showing calcification at insertion of longissimus coli (orange arrow). 
CTLC prevented any unnecessary intervention and allowed for a full recovery.

\section{Learning points}

- Acute calcific tendonitis of longus colli (CTLC) is a rare condition that usually presents with neck pain and stiffness.

- Fluid collections caused by CTLC associated oedema can resemble abscess formation in the retropharyngeal area.

- After excluding other causes of neck pain, the mainstay of treatment is anti-inflammatory medications and physiotherapy.

Contributors $A B$ am the main author and contributor to the report. $A B$ researched the patient and wrote the main body of text, and is responsible for all submissions and correspondence. Other co-authors include NW who assisted in editing the text and providing images for the report. AW another co-author, also contributed to editing of text and application process. CD was responsible for final review of text and was the consultant responsible for managing and identifying the patient for publication.
Funding The authors have not declared a specific grant for this research from any funding agency in the public, commercial or not-for-profit sectors.

Competing interests None declared.

Patient consent for publication Consent obtained directly from patient(s). Provenance and peer review Not commissioned; externally peer reviewed. Case reports provide a valuable learning resource for the scientific community and can indicate areas of interest for future research. They should not be used in isolation to guide treatment choices or public health policy.

\section{REFERENCES}

1 Ulloa N, Gill J, Childress J. Acute calcific Tendonitis of the longus colli: an uncommon cause of neck pain in the emergency department. Cureus 2020;12:7.

2 Shin D-E, Ahn C-S, Choi J-P. The acute calcific prevertebral tendinitis: report of two cases. Asian Spine J 2010:4:123-7.

3 Siag K, Mazzawi S, Paker M, et al. Acute longus colli tendinitis and otolaryngology. Braz J Otorhinolaryngol 2020. doi:10.1016/j.bjorl.2020.10.018. [Epub ahead of print: 05 Dec 2020].

4 Eastwood JD, Hudgins PA, Malone D. Retropharyngeal effusion in acute calcific prevertebral tendinitis: diagnosis with CT and MR imaging. AJNR Am J Neuroradiol 1998;19:1789-92

Copyright 2022 BMJ Publishing Group. All rights reserved. For permission to reuse any of this content visit https://www.bmj.com/company/products-services/rights-and-licensing/permissions/

BMJ Case Report Fellows may re-use this article for personal use and teaching without any further permission.

Become a Fellow of BMJ Case Reports today and you can:

- Submit as many cases as you like

- Enjoy fast sympathetic peer review and rapid publication of accepted articles

- Access all the published articles

Re-use any of the published material for personal use and teaching without further permission

\section{Customer Service}

If you have any further queries about your subscription, please contact our customer services team on +44 (0) 2071111105 or via email at support@bmj.com.

Visit casereports.bmj.com for more articles like this and to become a Fellow 